\title{
Contrasting effects of enalapril and metoprolol on proteinuria in diabetic nephropathy
}

\author{
Staffan Björck, Henrik Mulec, Svend Aage Johnsen, Gudrun Nyberg, Mattias Aurell
}

Abstract

Objective-To assess whether angiotensin converting enzyme inhibition reduces proteinuria in diabetic nephropathy more than blood pressure reduction with other antihypertensive treatment.

Design-Prospective, open randomised study lasting eight weeks in patients with diabetic nephropathy.

Setting-Outpatient nephrology clinics.

Patients-40 Patients with type I diabetes and diabetic nephropathy with reduced renal function.

Intervention-Antihypertensive treatment with enalapril or metoprolol, usually combined with frusemide.

Main outcome measures-Arterial blood pressure and urinary excretion of albumin and protein.

Results - Arterial blood pressure after eight weeks was $135 / 82$ (SD 13/7) $\mathrm{mm} \mathrm{Hg}$ in the group given enalapril and 136/86(16/12) $\mathrm{mm} \mathrm{Hg}$ in the group given metoprolol. Proteinuria and albuminuria were similar in both groups before randomisation. After eight weeks' treatment, the geometric mean albumin excretion was $0.7(95 \%$ confidence interval 0.5 to 1.2$) \mathrm{g} / 24 \mathrm{~h}$ in the patients given enalapril and $1 \cdot 6(1 \cdot 1$ to $2 \cdot 5) \mathrm{g} / 24 \mathrm{~h}$ in the patients given metoprolol $(p<0.02)$. The proteinuria was $1.1(0.7$ to 1.7$)$ and $2.4(1.6$ to 3.6$)$ g/24 h respectively $(\mathbf{p}<0.02)$.

Conclusions-Antihypertensive treatment with enalapril reduced proteinuria in patients with diabetic nephropathy more than an equally effective antihypertensive treatment with metoprolol. This points to a specific antiproteinuric effect of the angiotensin converting enzyme inhibitor independent of the effect on systemic blood pressure.

Department of

Nephrology, Sahlgrenska

Hospital, University of

Göteborg, S-413 45

Göteborg, Sweden

Staffan Björck, MD, registrar

Gudrun Nyberg, PHD,

registrar

Mattias Aurell, PHD, head

\section{Department of}

Nephrology, Northern

Älvsborg Hospital,

Trollhättan, Sweden

Henrik Mulec, MD, senior

registrar

\section{Department of}

Nephrology, Borås

Hospital, Sweden

Svend Aage Johnsen, PHD, senior registrar

Correspondence to: $\mathrm{Dr}$ Björck. function, and other diabetic complications such as retinopathy. They had a mean age of 42 (range 21-58) years and mean onset of diabetes at 17 (3-39) years of age. The mean duration of diabetes was 25 (13-45) years. All patients had retinopathy, and three patients were blind. The onset and development of the kidney disease had to be typical of diabetic nephropathy. If there was any suspicion of other renal disease then kidney biopsy was performed. This was done in four patients showing diabetic nephropathy only. Presence of hypertension was not an inclusion criteria, but only two patients were not being treated for hypertension before the study. The glomerular filtration rate was lower than our age adjusted normal value ${ }^{+}$but higher than $24 \mathrm{ml} / \mathrm{min} / 1 \cdot 73 \mathrm{~m}^{2}$.

Twenty two patients were randomised to enalapril and 18 to metoprolol. The initial goal was to include 60 patients but because previous treatment with angiotensin converting enzyme inhibitor was a criterion for exclusion there was a diminishing number of eligible patients in the participating centres owing to the increasing popularity of these drugs. The inclusion of new patients was therefore stopped after two years and 40 subjects. The study was performed after the patients' informed consent and approval by the local ethical committee had been obtained.

\section{TREATMENT}

Two weeks before the study, previous antihypertensive treatment was stopped except for frusemide. If this was considered unsafe, medication could be continued until two days before randomisation. The randomisation into two groups was done separately in the three centres and was stratified in three subgroups depending on renal function to ensure balance in this respect. On the day of the randomisation the patients received $5 \mathrm{mg}$ enalapril or $50 \mathrm{mg}$ metoprolol daily in addition to frusemide if it had been used before. Blood pressure was measured during the four hours after the first dose. The goal was a mean arterial blood pressure between 90 and $110 \mathrm{~mm} \mathrm{Hg}$ when patients were supine. The dose of enalapril was doubled every week to the final dose of 20,10 , or $5 \mathrm{mg}$ if the glomerular filtration rate was $>50,30-50$, or $<30 \mathrm{ml} / \mathrm{min} / 1.73 \mathrm{~m}^{2}$ respectively. The dose of metoprolol was doubled every week to a maximum of $200 \mathrm{mg}$ if the blood pressure was not satisfactory. If the blood pressure was not within the limits that had been set the dose of frusemide was increased or decreased. If necessary, hydralazine could be added.

We measured blood pressure and urinary protein and albumin excretion at baseline and weeks 1, 2, 3, 4, and 8 ; serum creatinine, sodium, and potassium concentrations at baseline and weeks 4 and 8; plasma renin activity at baseline and week 4 ; and haemoglobin $\mathrm{A}_{1 \mathrm{C}}$ concentration at baseline and week 8 .

Blood pressure was measured with a mercury sphygmomanometer by a nurse after the patient had rested for five minutes in the supine position and after one minute of standing. The mean of two readings on each occasion was used. Mean arterial pressure was calculated as diastolic blood pressure plus one third of
Forty patients with type I diabetes and nephropathy were studied. The patients were required to have type I diabetes, diabetic nephropathy, reduced renal 
the difference between systolic and diastolic blood pressure and is shown as the mean of standing and supine values unless otherwise stated.

Urinary protein excretion was measured in 24 hour collections of urine with the biuret method. Albumin excretion was measured by immunochemical turbidometric assay, electrophoresis, or immunoprecipitation assay, depending on the hospital. Plasma renin activity was measured by radioimmunoassay." The reference range in a group of healthy people was $0 \cdot 2-1 \cdot 2 \mathrm{nmol} / \mathrm{l} / \mathrm{h}$. The glomerular filtration rate was measured before the study as the rate of disappearance of chromium-51 edetic acid in plasma after a single injection.

\section{STATISTICS}

Results are presented as means (SD or range) except urinary albumin and protein excretion, serum creatinine concentration, and plasma renin activity, which are expressed as geometric means (antilog 95\% confidence interval of the logarithms). Student's two tailed $t$ test for paired and unpaired comparisons was used. Urinary albumin and protein excretion, serum creatinine concentration, and plasma renin activity were analysed after log transformation because of the skewed distributions, and significance was taken as $\mathrm{p}<0 \cdot 05$. Multiple linear regression analysis was used to determine the influence of mean arterial pressure and type of treatment on change in urinary albumin and protein excretion, which was fairly normally distributed, and on absolute values of urinary protein and albumin after log transformation. In addition, a sliding mean value method was used to describe the relation between blood pressure and urinary albumin and protein excretion. All urinary protein and albumin values were ranked according to the mean arterial pressure measured at the same time. A geometric mean was calculated on both albuminuria and proteinuria values for ranked measurements $1-19$, and the mean of the corresponding mean arterial pressures was calculated; then calculations were made on ranked measurements 2-20, and so on. The successive points were joined to form curves for the enalapril and the metoprolol patients (see fig 2). The sliding mean

Effect of two months' treatment with enalapril or metoprolol in 40 patients with diabetic nephropathy. V'alues are means $(S D)$ except for urinary protein and albumin values, serum creatinine concentration, and plasma renin activity, which are geometric means (antilog 95\% confidence interval of the logarithms)

\begin{tabular}{|c|c|c|c|}
\hline & Baseline & 4 Weeks & 8 Weeks \\
\hline \multicolumn{4}{|c|}{ Supine blood pressure $(\mathrm{mm} \mathrm{Hg})$ : } \\
\hline Enalapril group & $163 / 96(17 / 9)$ & 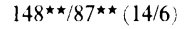 & $141^{\star \star / 83^{\star \star}}(13 / 8)$ \\
\hline Metoprolol group & $161 / 91(25 / 9)$ & $155 / 90(23 / 8)$ & $148^{\star} / 89(18 / 12)$ \\
\hline \multicolumn{4}{|c|}{ Standing blood pressure $(\mathrm{mm} \mathrm{Hg})$ : } \\
\hline Enalapril group & $147 / 91(18 / 9)$ & $131^{\star \star / 84^{\star \star}(15 / 8)}$ & $128^{\star \star / 81 \star \star(16 / 8)}$ \\
\hline Metoprolol group & $140 / 87(20 / 9)$ & $128 / 83(19 / 9)$ & $123^{\star \star / 83(19 / 13)}$ \\
\hline \multicolumn{4}{|c|}{ Mean arterial pressure $(\mathrm{mm} \mathrm{Hg}) t$ : } \\
\hline Enalapril group & 1148 & $103^{\star \star(5)}$ & $99(7)^{\star \star}$ \\
\hline Metoprolol group & $109(10)$ & $105(10)$ & $102(11)^{\star}$ \\
\hline \multicolumn{4}{|c|}{ Urinary protein excretion $(\mathrm{g} / 24 \mathrm{~h})$ : } \\
\hline Enalapril group & $2 \cdot 0(1 \cdot 3$ to $3 \cdot 0)$ & $1 \cdot 3(0 \cdot 8 \text { to } 2 \cdot 1)^{\star \star}$ & $1 \cdot 1(0.7 \text { to } 1 \cdot 7)^{\star \star \ddagger}$ \\
\hline Metoprolol group & $2 \cdot 0(1.4$ to $2 \cdot 8)$ & $2 \cdot 2(1 \cdot 5$ to $3 \cdot 2)$ & $2.4(1.6$ to 3.6$)$ \\
\hline \multicolumn{4}{|c|}{ Urinary albumin excretion $(\mathrm{g} / 24 \mathrm{~h})$ : } \\
\hline Enalapril group & $1 \cdot 6(1 \cdot 1$ to $2 \cdot 5)$ & $1.0(0.6 \text { to } 1.5)^{\star}$ & $0.7(0.5 \text { to } 1.2)^{\star \star \ddagger}$ \\
\hline Metoprolol group & $1.4(0.9$ to $2 \cdot 0)$ & $1 \cdot 7(1 \cdot 0$ to $3 \cdot 1)$ & $1 \cdot 6(1 \cdot 1$ to $2 \cdot 5)$ \\
\hline \multicolumn{4}{|c|}{ Serum creatinine $(\mu \mathrm{mol} / \mathrm{l})$ : } \\
\hline Enalapril group & $159(138$ to 183$)$ & $168(142$ to 200$)$ & $171(147 \text { to } 200)^{\star}$ \\
\hline Metoprolol group & $142(123$ to 164$)$ & $146(125$ to 170$)$ & $146(125$ to 171$)$ \\
\hline \multicolumn{4}{|c|}{ Serum sodium $(\mathrm{mmol} / \mathrm{l})$ : } \\
\hline Enalapril group & $138(5)$ & 1384 & $137(4)$ \\
\hline Metoprolol group & 1384 & $138(3)$ & $137(3)$ \\
\hline \multicolumn{4}{|c|}{ Serum potassium $(\mathrm{mmol} / \mathrm{l})$ : } \\
\hline Enalapril group & $4 \cdot 4(0 \cdot 5)$ & $4 \cdot 7(0 \cdot 5)^{\star}$ & $4 \cdot 8(0 \cdot 6)^{\star \star} \ddagger$ \\
\hline Metoprolol group & $4 \cdot 3(0 \cdot 4)$ & $4.8(0.5)^{\star \star}$ & $4 \cdot 2(0 \cdot 5)^{+}$ \\
\hline \multicolumn{4}{|l|}{ Haemoglobin $A_{\mathrm{l}}(\%)$ : } \\
\hline Enalapril group & $9 \cdot 3(1 \cdot 6)$ & & $9 \cdot 4(1 \cdot 9)$ \\
\hline Metoprolol group & $9 \cdot 6 \cdot 2 \cdot 1)$ & & $9 \cdot 4(2 \cdot 4)$ \\
\hline \multicolumn{4}{|c|}{ Plasma renin activity $(\mathrm{nmol} / \mathrm{h})$ : } \\
\hline Enalapril group & $1 \cdot 5(1 \cdot 2$ to $2 \cdot 0)$ & $5.6(3.6$ to 8.6$)$ & \\
\hline Metoprolol group & 1.71 .1 to 2.6 & $1.2(0.8 \text { to } 1.7)^{\star \star}$ & \\
\hline
\end{tabular}

${ }^{\star} \mathrm{p}<0 \cdot 05,{ }^{\star \star} \mathrm{p}<0.01 \approx$ baseline.

†Based on mean of supine and standing blood pressure.

$\ddagger \mathrm{p}<0 \cdot 02$, enalapril $a$ metoprolol.

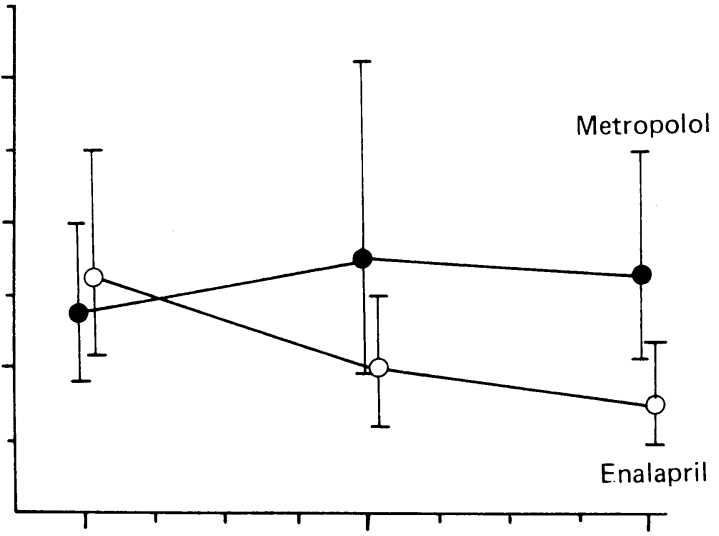

FIG 1-Blood pressure in 40 patients with diabetic nephropathy treated with enalapril or metoprolol. Values are means $(S D)$ and are the mean of supine and standing blood pressure
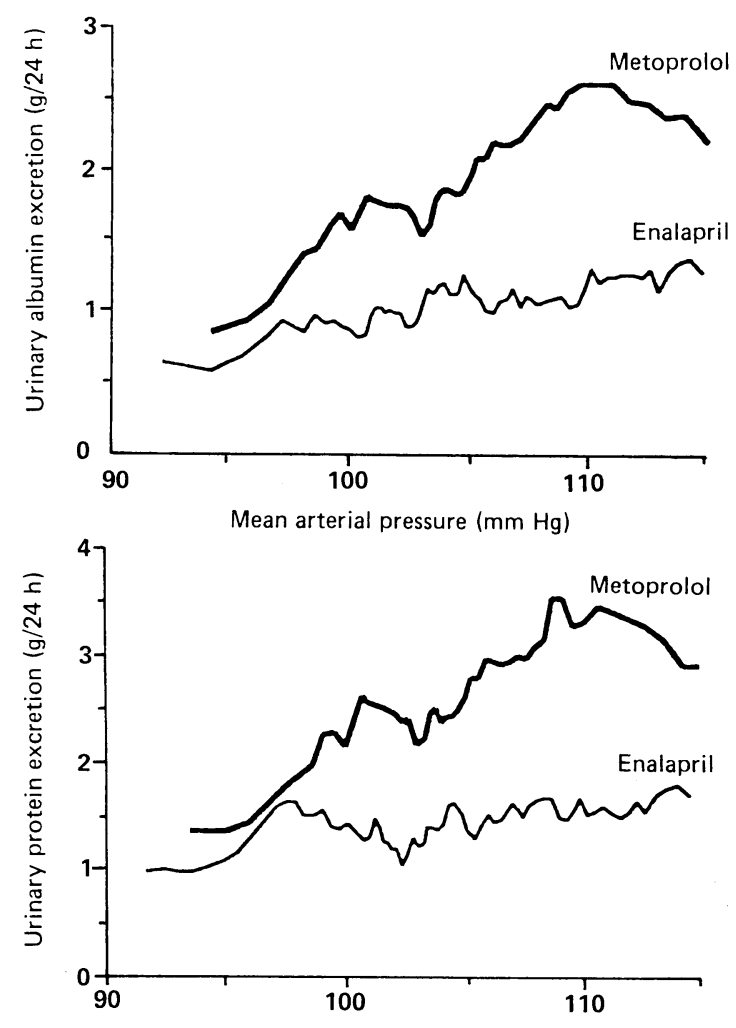

Mean arterial pressure $(\mathrm{mm} \mathrm{Hg})$

FIG 2-Relation between mean arterial pressure and albuminuria (top) and proteinuria (bottom) in 40 patients randomised to treatment with either enalapril or metoprolol. Lines represents sliding mean values of relation between all simultaneous measurements of mean arterial blood pressures and urinary albumin and protein excretion during treatment

calculations and graphs were made with Cricket Graph (Cricket Software, Malvern, Pennsylvania).

\section{Results}

After randomisation two patients given metoprolol were withdrawn from the study because of adverse reactions, but they are included in the results for as long as they participated. The first patient had a severe hypotensive response after the first $50 \mathrm{mg}$ dose of metoprolol. The second patient had unacceptable drowsiness and was withdrawn from the study after two weeks' treatment.

On the day before randomisation the enalapril patients were treated with 58 (range $0-160$ ) $\mathrm{mg}$ of frusemide and the metoprolol group with $117(0$ $375) \mathrm{mg}$. After eight weeks the group given enalapril was treated with $96(0-500) \mathrm{mg}$ frusemide and 11 (SD 6) mg enalapril. The group given metoprolol received 
$168(0-500) \mathrm{mg}$ frusemide and $138(67) \mathrm{mg}$ metoprolol. One patient in the group given metoprolol was also given hydralazine, $75 \mathrm{mg}$ daily. The table shows the results.

\section{BLOOD PRESSURES}

After the first dose the blood pressure fell in both groups to the same extent. During eight weeks' treatment similar blood pressure levels were obtained in both groups (table, fig 1). Systolic blood pressure was significantly reduced at eight weeks in the group given metoprolol (fig $1 ; \mathrm{p}<0.01$ ). In the group given enalapril both the systolic and diastolic blood pressure was significantly reduced throughout. There were no significant differences in blood pressure between the groups.

The reduction in blood pressure compared with baseline was significantly higher in the patients given enalapril as they had had slightly higher blood pressure before randomisation than the patients given metoprolol. The fall in orthostatic blood pressure during treatment tended to be smaller in the patients given enalapril. Four hours after the first dose was given the mean arterial pressure fell a mean of 7 (12) $\mathrm{mm} \mathrm{Hg}$ in the patients given enalapril and $16(10) \mathrm{mm} \mathrm{Hg}$ in the patients given metoprolol $(p<0 \cdot 05)$, and it differed significantly between the two groups after the first week of treatment, falling by $6(8) \mathrm{p} " \mathrm{~mm} \mathrm{Hg}$ and 12 (9) $\mathrm{mm} \mathrm{Hg}$, respectively $(\mathrm{p}<0.05)$.

\section{PROTEIN EXCRETION}

The urinary albumin and protein excretion decreased to half the initial value in the patients given enalapril but did not change in those given metoprolol (table). After eight weeks the urinary protein excretion was significantly correlated with mean arterial blood pressure $(r=0.37 ; p<0.05)$. The reduction in proteinuria and albuminuria was, however, not correlated with the reduction in mean arterial blood pressure in all patients or in either group.

Thus both the type of treatment and blood pressure were related to proteinuria. This dual relationship between proteinuria, type of treatment, and mean arterial pressure is shown in figure 2. After further analvsis with multiple linear regression both mean arterial pressure and the type of type of treatment were correlated with excretion of albumin and protein at eight weeks ( $p<0.05$ for both variables). In addition, when all simultaneous albumin excretion values and mean arterial pressure measurements throughout the study were analysed together, both the type of treatment and mean arterial pressure were correlated with albuminuria or proteinuria $(\mathrm{p}<0.001$ for both explanatory variables). With the same analysis, the type of treatment was related to reduction in albuminuria after two months $(p<0.01)$ but not to reduction in mean arterial pressure $(p=0.56)$. The same applied to reduction in proteinuria $(\mathrm{p}<0.01$ and $\mathrm{p}=0.71$, respectively). Generally, protein excretion was more closely correlated with mean arterial pressure, calculated as the mean of supine and standing blood pressure, than with either supine or standing mean arterial pressure. The initial frusemide dose was not correlated with proteinuria $(\mathrm{r}=0 \cdot 057)$.

Laboratory values - The glomerular filtration rate before the study was $48(15) \mathrm{ml} / \mathrm{min} / 1.73 \mathrm{~m}^{2}$ in the patients given metoprolol and $46(14) \mathrm{ml} / \mathrm{min} / 1.73 \mathrm{~m}^{2}$ in those given enalapril. Serum creatinine concentrations increased slightly but significantly in the patients given enalapril but not in those given metoprolol (table). Serum potassium rose after enalapril was given. There was no change in haemoglobin $A_{1 c}$ concentration in either group. The baseline plasma renin activity was significantly higher in patients than in healthy controls $(p<0 \cdot 01)$, and increased in the group given enalapril and decreased in the group given metoprolol

\section{Discussion}

This study showed that proteinuria and albuminuria could be reduced by two months' treatment with enalapril to less than half the values obtained in a control group treated with metoprolol. As expected, higher blood pressure was linked to more proteinuria. The blood pressure was similar in both groups, and it is likely that the lower level of proteinuria during treatment with enalapril is produced by a mechanism independent of systemic blood pressure. This pressure independent effect is shown in figure 2. It seems plausible that this is an effect of changes in the rena haemodynamics caused by these drugs. Angiotensin converting enzyme inhibitors can induce and increase in renal blood flow without a concomitant reduction in glomerular filtration rate in this category of patients. This leads to a decrease in filtration fraction, which probably reflects a lowering of glomerular filtration pressure.

Reduction of blood pressure with different antihypertensive drugs in patients with incipient or overt diabetic nephropathy leads to a reduction in urinary protein excretion. ${ }^{26-8}$ Treatment with an angiotensin converting enzyme inhibitor usually ${ }^{9-15}$ but not always ${ }^{16-20}$ results in reduced proteinuria in these patients. The experimental design in these studies, however, failed to distinguish between the effect of blood pressure reduction itself and other effects of angiotensin converting enzyme inhibitors; no control groups given other types of antihypertensive treatment were used.

Insua et al, however, made this comparison and investigated the effect on microalbuminuria of six weeks' treatment with captopril in eight type I diabetic patients and of nifedipine in seven and found that captopril reduced but nifedipine increased microalbuminuria. ${ }^{21}$ In contrast, Baba et al found nicardipine to be as effective as enalapril in reducing microalbuminuria in seven type II diabetic patients. ${ }^{22}$ One explanation for these diverging results is given by Heeg et al, who found that lisinopril reduced proteinuria in patients with the nephrotic syndrome only if sodium was reduced in the patients' diet. ${ }^{23}$ This indicates that an active renin-angiotensin system enhances the antiproteinuric effect of angiotensin converting enzyme inhibitors. As higher renin concentrations could be anticipated in the patients with type I diabetes studied by Insua $e t \mathrm{al}^{24}$ they could have been more susceptible to this effect of the angiotensin converting enzyme inhibitor than the type II diabetic patients in the study by Baba et al. The baseline plasma renin activity was higher in the present study than our normal value. We found earlier that patients with type I diabetes and nephropathy had higher renin levels than patients with other types of renal disease provided that overhydration was treated with frusemide..$^{25}$ In our previous prospective long term study of captopril in patients with diabetic nephropathy we did not observe an antiproteinuric effect of that angiotensin converting enzyme inhibitor. ${ }^{3}$ Most patients showed a reduction in proteinuria, but this did not reach statistical significance during the long term follow up.

In the present study the reduction in blood pressure in the patients given enalapril was somewhat greater than in those given metoprolol owing to a tendency to higher blood pressure before the study in those given enalapril. The blood pressure was comparable in both groups during treatment, so this is unlikely to explain the difference in level of proteinuria. During treatment, both blood pressure and treatment with enalapril had a 
significant influence on the degree of proteinuira, as shown in figure 2 . There was no correlation between the fall in blood pressure and the reduction in proteinuria in either group or in the whole study population. The mean supine and standing blood pressure was best correlated with proteinuria and may therefore reflect the blood pressure throughout the day more accurately than either supine or standing blood pressure.

Although the blood pressure was similar for both treatments a tendency to higher supine and lower standing blood pressure was found in the group given metoprolol. When this was calculated as the orthostatic fall in blood pressure, there was a trend towards more orthostatic hypotension in the group given metoprolol, and this difference was significant after the first test dose and after one week. Enalapril therefore offers an advantage in this respect in these patients, who are prone to orthostatic hypotension. Enalapril was well tolerated, but two patients given metoprolol had side effects severe enough to require withdrawal of metoprolol.

The group given enalapril showed a small increase in serum creatinine concentration. If this represents a true fall in glomerular filtration rate the reduction is too small to explain the $56 \%$ reduction in albuminuria in this group. For unknown reasons there was a transient increase in serum potassium concentration in the group given metoprolol at four weeks. In the group given enalapril serum potassium concentration rose at eight weeks, although this increase was moderate and did not necessitate change of treatment in any patient. However, this supports the conclusion that angiotensin converting enzyme inhibitors should be used in these patients only after treatment with a diuretic, to ensure that they do not develop hyporeninaemic hypoaldosteronism, which could aggravate hyperkalaemia. It has been argued that diuretic treatment might increase proteinuria and worsen the prognosis in diabetic nephropathy, ${ }^{26}$ but this fear does not seem warranted because the lowest rate of deterioration so far reported in diabetic nephropathy is during treatment with a combination of antihypertensive drugs including high doses of frusemide. ${ }^{2}$ It can also be speculated that the antiproteinuric effect of enalapril might have been smaller without pretreatment with a diuretic. ${ }^{23}$

It is uncertain whether reducing proteinuria will benefit the kidneys in the long term, but it seems logical to assume that this antiproteinuric effect reflects a beneficial effect on mechanisms harmful to the kidneys. In addition, proteinuria, irrespective of origin, has been claimed to perpetuate the process of glomerulosclerosis."

Our results points to the conclusion that angiotensin converting enzyme inhibitors reduce proteinuria in diabetic nephropathy by a mechanism independent of the effect on systemic blood pressure. Whether the specific renal effects of angiotensin converting enzyme inhibitors lead to better preservation of kidney function, as indicated in our previous report, ${ }^{3}$ has to be verified by long term studies.

The study was supported by grants from the Swedish Medical Research Council, project number 05230; the
Förenade Liv Mutual Group Life Insurance Company, Stockholm; and Merck Sharp \& Dohme. We thank the departments of chemistry at Sahlgrenska, Vänersborg, and Borås Hospitals for determining albumin and protein and blood chemistry.

1 Borch-Johnsen K, Andersen PK, Deckert T. The effect of proteinuria on relative mortality in type 1 (insulin dependent) diabetes mellitus. Diabetologia 1985;28:590-6.

2 Parving HH, Andersen AR, Smidt UM, Hommel E, Mathiesen ER, Svendsen PA. Effect of antihypertensive treatment on kidney function in diabetic nephropathy. Br.Med f 1987;294:1443-7.

3 Biörck S, Nyberg G, Mulec H, Granerus G, Herlitz H, Aurell M. Beneficial effects of angiotensin converting enzyme inhibition on renal function in patients with diabetic nephropathy. Br Med f 1986;293:467-70.

4 Granerus $G$, Aurell $M$. Reference values for Cr-EDTA clearance as a measure of glomerular filtration rate. Scand f Clin Lab Invest 1981;41:611-6.

5 Ikeda I, Iinuma $K$, Takai $M$, et al. Measurement of plasma renin activity by a simple solid phase radioimmunoassay. I Clin Endocrinol Metab 1981:54: simple $423-8$.

6 Mogensen CE. Progression of nephropathy in long-term diabetics with proteinuria and effect of initial antihypertensive treatment. Scand f C lin $L . a b$ Invest 1976;36:383-8.

7 Christenssen CK, Mogensen CE. Effect of antihypertensive treatment on progression of incipient diabetic nephropathy. Hypertension 1985;7:9-13.

8 Hommel E, Mathiesen E, Edsberg B, Bahnsen M, Parving HH. Acute reduction of arterial blood pressure reduces urinary albumin excretion in type 1 (insulin dependent) diabetic patients with incipient nephropathy. Diabetologia 1986;29:211-5.

9 Taguma Y, Kitamoto Y, Futaki G, et al. Effect of captopril on heavy proteinuria in azotemic diabetics. $N$ Engl f Med 1985;313:1617-20.

10 Hommel E, Parving HH, Mathiesen E, Edsberg B, Nielsen MD, Giese J. Effect of captopril on kidney function in insulin-dependent diabetic patients with nephropathy. $\operatorname{BrMed}$ f 1986;293:467-70.

11 Elving LD, Wetzels JMF, De Nobel E, Hoitsma AJ, Berden JHM. Captopril reduces proteinuria probably through lowering of intraglomerular pressure: acute effects in patients with diabetic nephropathy. Postgrad Med $f$ acute effects in patien
$1988 ; 64$ (suppl 3): 34 .

12 Marre M, LeBlanc H, Suarez L, Guyenne TT, Menard J, Passa P. Converting enzyme inhibiton and kidney function in normotensive diabetic patients with persisent microalbuminuria. BrMed f 1987;294:1448-52.

13 Parving HH, Hommel E, Smidt UM. Protection of kidney function and decrease in albuminuria by captopril in insulin dependent diabetics with nephropathy. BrMed f 1988;297:1086-91.

14 Casado S, Carrasco MA, Arrieta FJ, Herrera JL. Effects of captopril in diabetic patients with different degrees of blood pressure and proteinuria. Postgrad Med f 1988;64(suppl 3):84

15 D'Angelo A, Sartori L, Gambaro G, et al. Captopril in the treatment of hypertension in type I and type II diabetic patients. Postgrad Med $\mathcal{J}$ 1986;62(suppl 1):69-72.

16 Romanelli G, Giustina A, Cimino A. Short term effect of captopril on microalbuminuria induced by exercise in normotensive diabetics. Br Med $\mathcal{F}$ 1989:298:284-8.

17 Winocour PH, Waldek S, Anderson DC. Converting enzyme inhibition and kidney function in normotensive diabetic patients with persistent microalbuminuria. BrMed f 1987;295:391.

18 Passa $P$, LeBlanc $H$, Marre $M$. Effects of enalapril in insulin-dependen diabetic subjects with mild to moderate uncomplicated hypertension. Diabetes Care 1987;10:200-4

19 Valvo E, Bedogna V, Casagrande P, et al. Captopril in patients with type II diabetes and renal insufficiency: systemic and renal hemodynamic alterations. Am F Med 1988;85:344-8.

20 Hay U, Ludvik B, Gisinger Ch, Schernthaner G. Lack of influence of ACEinhibition on macroproteinuria in diabetic nephropathy: a long-term tria over 6 months. Postgrad Med J 1988;64(suppl 3):87.

21 Insua A, Ribstein J, Mimran A. Comparative effect of captopril and nifedipine in normotensive patients with incipient diabetic nephropathy. Postgrad Med f 1988;64(suppl 3):59.

22 Baba T, Murabayashi S, Takebe K. Comparison of the renal effects of angiotensin converting enzyme inhibitor and calcium antagonist in hypertensive type 2 (non-insulin-dependent) diabetic patients with microalbumintensive type 2(non-insulin-dependent) diabetic patients with micto
uria: a randomsied controlled trial. Diabetologia 1989;32:40-4.

23 Heeg JE, De Jong PE, van der Hem GK, de Zeeuw D. Efficacy and variability of the antiproteinuric effect of ACE inhibition by lisinopril. Kidney Int
ond

24 De Chatel R, Weidman P, Flammer J, et al. Sodium, renin, aldosterone, catecholamines and blood pressure in diabetes mellitus. Kidney In 1977;12:412-21.

25 Björck S, Delin K, Herlitz H, Larsson O, Aurell M. Renin secretion in advanced diabetic nephropathy. Scand $\mathcal{F}$ Urol Nephrol 1984;79(suppl):53-7.

26 Walker WG, Hermann J, Yin DP, Murphy RP, Patz A. Diuretics accelerate diabetic nephropathy in hypertensive insulin-dependent and non insulindependent subjects [Abstract]. Clin Res 1987;35:663.

27 Klahr S. The progression of renal disease. $N$ Engl f Med 1988;318:1657-66.

(Accepted 27 December 1989)
The danger of kissing a greasy book, so often tendered in police and law courts to a witness about to be sworn, is at last appreciated by some officials and in some quarters. We see it stated that when the Duke of Fife appeared lately at Stratford in a prosecution the Testament on which he took the oath was enveloped in some clean white paper for his use-a precaution which might with advantage be more generally adopted. Why should not the formula and method of taking the oath in English Courts of Justice be altered and adopted, possibly in imitation of the method adopted in Scotland, which is that of raising the hand in lieu of kissing the book? (British Medical fournal 1890;i:1494.) 